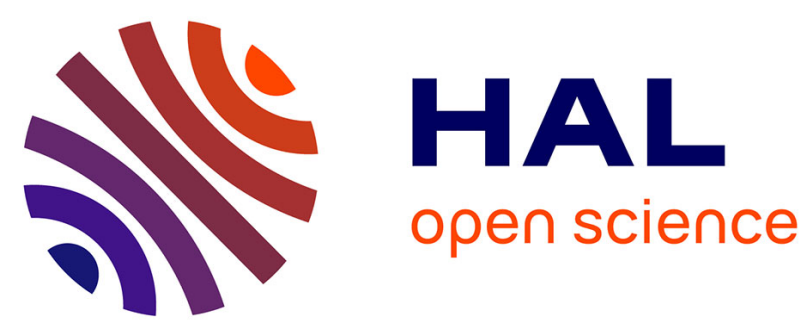

\title{
Assessment of Recovered Carbon Black Obtained by Waste Tires Steam Water Thermolysis: An Industrial Application
}

L. Moulin, S da Silva, Arezki Bounaceur, M Herblot, Yannick Soudais

\section{- To cite this version:}

L. Moulin, S da Silva, Arezki Bounaceur, M Herblot, Yannick Soudais. Assessment of Recovered Carbon Black Obtained by Waste Tires Steam Water Thermolysis: An Industrial Application. Waste and Biomass Valorization, 2017, 8 (8), p.2757-2770. 10.1007/s12649-016-9822-8 . hal-01915193

\section{HAL Id: hal-01915193 \\ https://imt-mines-albi.hal.science/hal-01915193}

Submitted on 7 Nov 2018

HAL is a multi-disciplinary open access archive for the deposit and dissemination of scientific research documents, whether they are published or not. The documents may come from teaching and research institutions in France or abroad, or from public or private research centers.
L'archive ouverte pluridisciplinaire HAL, est destinée au dépôt et à la diffusion de documents scientifiques de niveau recherche, publiés ou non, émanant des établissements d'enseignement et de recherche français ou étrangers, des laboratoires publics ou privés. 


\title{
Assessment of Recovered Carbon Black Obtained by Waste Tires Steam Water Thermolysis: An Industrial Application
}

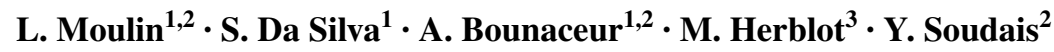

\begin{abstract}
Nearly 300 Millions of waste tires have to be managed in Europe. The main industrial ways to treat this kind of waste are incineration for energetic valorization and tires milling in chips or granulates for material valorization in construction industry. Steam water thermolysis (SWT) of tires, a hybrid of pyrolysis and solvolysis, is a good alternative to valorize waste tires. Recovered carbon black ( $\mathrm{rCB}$ ), which can be reintroduced in rubber industry as reinforcing filler (circular economy concept), is a more economical added value material than shredded tires. Physical and chemical characterizations on SWT-rCB were performed following ASTM analytical standards. A comparison between furnace carbon black (N330) and rCB from pyrolysis (commercial products) was carried out. Oil Absorption Number (ASTM D2414) and nitrogen adsorption (ASTM D6556) measurements demonstrate that rCBs structure and specific surface area are comparable to a furnace carbon black N330. According to data issued from ASTM standards, the behavior of $\mathrm{rCBs}$ reinforcement in rubbers is then expected to be equivalent to a N330 carbon black. Rubber compounds were produced with a homemade formula and mechanical characterizations were carried out in order to assess reinforcement properties of SWT-rCB. Comparisons in terms of mechanical properties have been established between rubbers reinforced with $100 \%$ of SWT-rCB, rubbers reinforced with furnace carbon blacks (N330, N550 and N772), and mixtures of SWT-rCB and furnace carbon
\end{abstract}

S. Da Silva

s.dasilva@alpharecyclage.com

Alpha Recyclage, Toulouse, France

2 Université de Toulouse, Mines Albi, CNRS, Centre RAPSODEE, Albi, France

3 LRCCP, Vitry-sur-Seine, France blacks. The results clearly show that rCBs reinforcement properties are lower than those of N330 carbon black. However, for a same rubber formula, SWT-rCB filled rubbers properties are close or slightly better than N550 and N772 filled rubbers.

Keywords Waste tires - Recovered carbon black · Steam water thermolysis · Physico-chemical properties · Mechanical properties

\section{Introduction}

Each year in Europe, over 300 millions of tires are removed from passenger cars, utility vehicles or trucks and become waste that need to be managed [1]. Since the EU Waste Landfill Directive regulation (1999/31/EC), these waste tires can no longer be sent to landfill disposal due to obvious environmental issues, thus they have to be valorized in different ways. The available options for the treatment of waste tires and the foreseen beneficial re-uses of such waste as recovered materials or alternative fuels have been reviewed by Sienkiewicz et al. [2] Fig. 1 shows the distribution of the waste tires valorization routes in Europe for 2014. Approximately $35 \%$ of the waste tires were used as solid fuel for energetic valorization mainly in cement kilns and incinerators, while $38 \%$ were used for material recovery ranging from shredded chips or granulates employed in civil engineering applications to feedstock for rubber reclaim [3]. However, because regulation and economical context are being increasingly restrictive for waste tires treatment industries, especially regarding the incineration treatment route for which another European Directive (2000/76/EC) has been initiated, studies have been conducted to develop environmentally friendly, technical and 


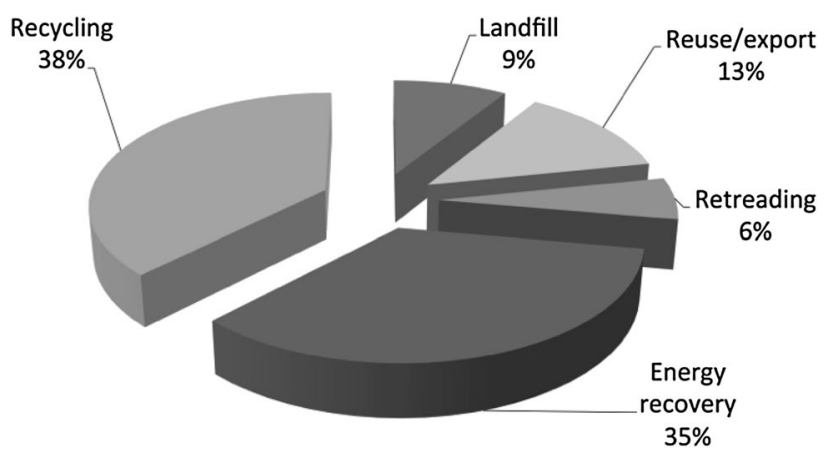

Fig. 1 EU waste tires valorization routes of 2014 [1]

economical efficient processes able to recover high added value materials [4].

For many years now, pyrolysis technologies have been targeted as some of the most promising alternatives for the treatment of tires. Pyrolysis consists in a thermochemical decomposition of organic materials and proceeds under non-oxidative conditions at elevated temperatures, typically ranging from 400 to $800^{\circ} \mathrm{C}$. In addition to being an efficient process in terms of energy recovery, the pyrolysis treatment of waste tires is considered to be a clean thermochemical process with nearly no emissions or residual waste [5]. When performed under suitable conditions, the process basically produces char or recovered carbon black (rCB), oil and gases, along with the recovery of steel originally found in the tire, all of which have the potential to be re-used. To treat this kind of waste, several types of reactors and operating conditions have been tested and described by different research groups in the past, from which extensive reviews on the topic by Williams [3] and Martinez et al. [6] have been realized. It is now acknowledged that pyrolysis conditions and parameters should be carefully controlled depending on the desired end-products yield and quality output. The pyrolytic oil generated from the pyrolysis treatment of tires is often recovered as fuel for its calorific value [7] but can also be used as a source of refined chemicals such as limonene [8]. The gas generated is usually used to supply the heating system of the process and in most cases, is even self-sufficient regarding energy needs [6]. The char fraction obtained from the pyrolysis of waste tires has been widely studied in the literature, yet the low value of this product substantially related to its quality has remained the fundamental issue with regards to high operating costs on an industrial scale plant.

Steam water thermolysis (SWT), a hybrid of pyrolysis and solvolysis is an efficient alternative among the thermochemical methods treating waste tires for materials recovery. The process uses superheated steam as an additional factor of heating the waste tires within the reactor.
More than just enhancing the energy input, this superheated steam increases the explosion proofness of the gas in the reactor, reduces the sulfur content in the fuel condensate [9] and is expected to act as a catalyst. In addition to the advantages just mentioned, a recent study [10] has shown that SWT is more efficient than conventional pyrolysis at the same treatment conditions for the recovery of carbon fibers from carbon fiber reinforced polymer waste.

Even tough the char product can be used as activated carbon [11-14], as filler in reinforced bitumen or in the ink industry [15], the objective is to valorize the $\mathrm{rCBs}$ from SWT of waste tires with a good economical added value, and one of the best ways to do so is to reintroduce them in rubber products as reinforcing fillers.

ASTM key parameters for the use of rCBs as reinforcing fillers in the rubber industry are structure and surface area. Previous studies including rCBs physicochemical characterizations [15-19], have attested a surface area ranging from 60 to $95 \mathrm{~m}^{2} / \mathrm{g}$ and a structure around $80 \mathrm{~mL} / 100 \mathrm{~g}$, depending on pyrolysis processes and conditions. According to ASTM (American Society for Testing and Materials) standard classification, such results suggest a reinforcing potential close to N300 rubber-grade carbon blacks. Several studies using rCBs as partial or total virgin carbon black substitutes have been carried out to evaluate and investigate their reinforcing potential in rubber compounds such as NR/SBR blends [20, 21], SBR [19, 22, 23] or EPDM [24]. The results obtained for the mechanical behavior of these vulcanized rubbers have been inferior to what was expected by physical and chemical characterizations following ASTM analytical standards. In most cases, the high inorganic fraction of the $\mathrm{rCB}$, generally fluctuating from 10 to $30 \mathrm{wt} \%$ due to different waste tires feedstock used, has been pointed out as the main responsible, as well as a decrease in particle surface activity, for the decrease on inrubber performance.

In this paper we studied the SWT of waste tires to recover rCBs. Physical and chemical characterizations have been carried out to predict the reinforcing properties of the carbon fillers. These analyses have been followed by the evaluation of the rCBs filler effect upon the mechanical properties of vulcanized rubbers.

\section{Materials and Methods}

\section{Waste Tires Samples}

The tires disposal company SOREGOM has provided the samples of shredded waste tires used in this study. These samples are typically shaped as rectangles of $2 \times 3 \mathrm{~cm}^{2}$ and come from whole light vehicles tires. 


\section{Recovered Carbon Black (rCB)}

rCBs were produced by SWT of waste tires samples at two different pilot scales; from the laboratory bench scale reactor (samples rCB_1, rCB_2, until rCB_6) up to the pre-industrial continuous pilot reactor with a capacity of $200 \mathrm{~kg} / \mathrm{h}$ (rCB_ind). Details on the conditions for the laboratory pilot experiments are given in "Pilot and Protocol" section of this study. The pre-industrial process was conducted according to a method for treating carbonaceous materials by vapour thermolysis (Patent no. WO2014135754 [25]). An additional rCB sample comes from the treatment in the laboratory reactor of a modelformulated rubber filled with virgin N330 carbon black (rCB_N330).

\section{Model Laboratory Filled Rubbers}

\section{Raw Materials Selection}

The descriptions of the selected formulations for dumping applications are provided in Table 1. Two rCBs ( $\mathrm{rCB}_{-}$ind and rCB_N330) were used in comparison with three virgin carbon blacks (CB): N772, N550 and N330 respectively for low, medium and high level of reinforcement.

\section{Compounding Equipment and Processing Conditions}

Considering compounding process, all formulations were blended in a $1.5 \mathrm{~L}$ Banbury mixer. The accelerators and sulfur were incorporated on a roll mill $300 \times 700 \mathrm{~mm}$ equipped
Table 2 Mixing process conditions

\begin{tabular}{ll}
\hline $\begin{array}{l}\text { Initial temperature: } 60^{\circ} \mathrm{C} \\
\text { Rotors speed: } 60 \mathrm{rpm} \\
\text { Fill factor: } 0.64\end{array}$ \\
\hline Timing & \\
(Min. sec.) & Incorporation process of ingredient \\
\hline 0.00 & $\mathrm{NR}$ \\
1.00 & Protecting agents, $\mathrm{ZnO}+$ stearic acid \\
1.30 & $1 / 2 \mathrm{CB}$ or rCB \\
2.30 & $1 / 2 \mathrm{CB}$ or rCB \\
3.30 & Sweep \\
4.30 & Rotors speed up to $80 \mathrm{rpm}$ \\
5.00 & Dump \\
\hline
\end{tabular}

with a cooling device. Table 2 presents the mixing conditions common to every compound.

\section{Curing Conditions and Samples}

Cure time was determined by rheometric measurements for each formula: i.e. $\mathrm{t}_{98}$ at $160^{\circ} \mathrm{C}$. All compounds were compression moulded on $300 \times 300 \times 2 \mathrm{~mm}$ in size sheet, compression set plots and sheet for fatigue test.

\section{Pilot and Protocol}

Experiments were conducted in a bench-scale reactor composed of a vertical cylinder tube furnace surrounded by heating coils, with a $1 \mathrm{~L}$ alumina crucible as shown in Fig. 2. The reactor is pre-heated at a target temperature
Table 1 Description of the rubber-based formulations

\begin{tabular}{|c|c|c|c|c|c|c|}
\hline \multirow[t]{3}{*}{ Ingredient } & \multicolumn{6}{|c|}{ Rubber compounds } \\
\hline & $\mathrm{N} 772$ & N550 & N330 & $100 \%$ & $50 / 50$ & $20 / 80$ \\
\hline & $\mathrm{phr}$ & $\mathrm{phr}$ & $\mathrm{phr}$ & $\mathrm{phr}$ & $\mathrm{phr}$ & phr \\
\hline $\mathrm{NR}^{\mathrm{a}}$ & 100 & 100 & 100 & 100 & 100 & 100 \\
\hline N772 & 50 & & & & & \\
\hline N550 & & 50 & & & & \\
\hline N330 & & & 50 & & 25 & 40 \\
\hline rCB_ind or rCB_N330 & & & & 50 & 25 & 10 \\
\hline Stearic Acid & 2 & 2 & 2 & 2 & 2 & 2 \\
\hline $\mathrm{ZnO}$ & 3 & 3 & 3 & 3 & 3 & 3 \\
\hline $6 \mathrm{PPD}^{\mathrm{b}}$ & 1.5 & 1.5 & 1.5 & 1.5 & 1.5 & 1.5 \\
\hline Antilux $500^{c}$ & 2 & 2 & 2 & 2 & 2 & 2 \\
\hline Sulfur & 1.1 & 1.1 & 1.1 & 1.1 & 1.1 & 1.1 \\
\hline $\mathrm{CBS}^{\mathrm{d}}$ & 1.1 & 1.1 & 1.1 & 1.1 & 1.1 & 1.1 \\
\hline Total & 161 & 161 & 161 & 161 & 161 & 161 \\
\hline
\end{tabular}

${ }^{a}$ Natural rubber $10 \mathrm{CV} 60$

${ }^{\mathrm{b}}$ Antiozonant $N$-phenyl- $N$ '-1,3-dimethylbutyl-p-phenylenediamine

${ }^{\mathrm{c}}$ Antiozonant and weather protector wax

${ }^{\mathrm{d}}$ Accelerator $\mathrm{N}$-cyclohexyl-2-benzothiazole sulfenamide 


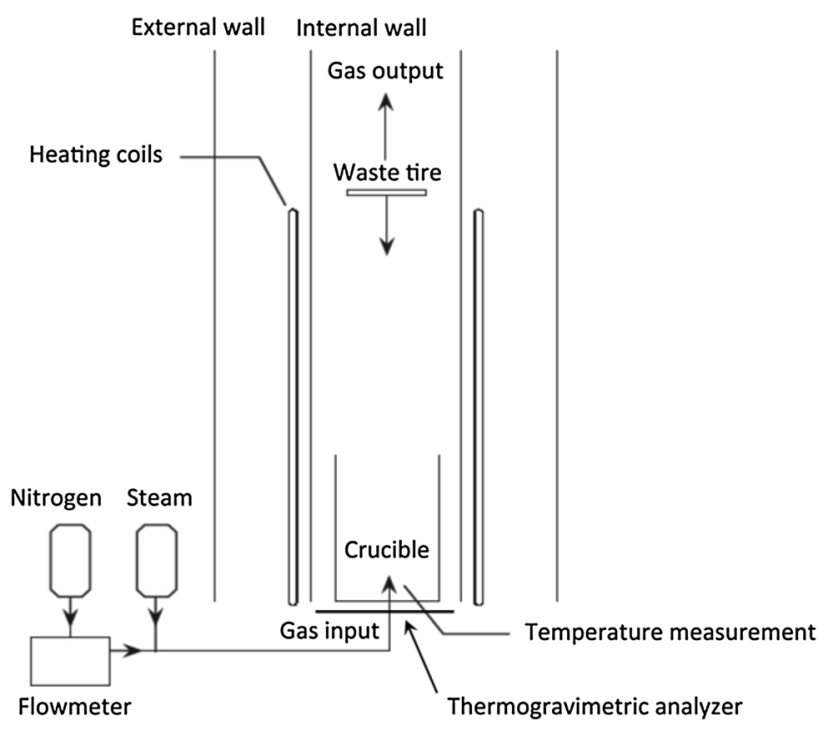

Fig. 2 Simplified diagram of the steam water thermolysis recycling process [26]

Table 3 Operating conditions applied to the steam water thermolysis unit for waste tires from light vehicles and the model laboratory N330 filled rubber

\begin{tabular}{lllll}
\hline Samples & $\begin{array}{l}\text { Tempera- } \\
\text { ture }\left({ }^{\circ} \mathrm{C}\right)\end{array}$ & $\begin{array}{l}\text { Residence } \\
\text { time }(\mathrm{min})\end{array}$ & $\begin{array}{l}\text { Nitrogen flow } \\
\text { rate }(\mathrm{L} / \mathrm{min})\end{array}$ & $\begin{array}{l}\text { Steam } \\
\text { flow rate } \\
(\mathrm{g} / \mathrm{h})\end{array}$ \\
\hline rCB_1 & 450 & 30 & 5 & 30 \\
rCB_2 & 500 & 30 & 5 & 30 \\
rCB_3 & 450 & 60 & 5 & 30 \\
rCB_4 & 500 & 60 & 5 & 30 \\
rCB_5 & 450 & 30 & 0 & 30 \\
rCB_6 & 450 & 60 & 0 & 30 \\
rCB_330 & 450 & 30 & 0 & 30 \\
\hline
\end{tabular}

measured by a thermocouple located at the bottom of the crucible, prior to the loading operation. It allows us to simulate at best the semi-continuous industrial process. Once the desired temperature is reached, the waste tires samples are introduced using a knife gate valve located in the upper part of the furnace and fall directly into the crucible. The reactor is connected to the steam generator providing the superheated steam and a nitrogen input. The superheated steam at $180^{\circ} \mathrm{C}$ mixed with nitrogen is introduced through six opening holes at the bottom of the crucible. When the isothermal residence time set is reached, heating and steam introduction are stopped and the system is cooled down under nitrogen to room temperature at a constant rate of $5^{\circ} \mathrm{C} / \mathrm{min}$. The solid part was collected from the reactor and rCBs were recovered after separation from the remaining steel. A thermogravimetric analyzer located under the crucible is used to track the weight loss during the reaction.
Table 3 describes rCB samples designation and conditions presented in this study.

\section{Pre-treatment: Grinding of rCBs}

Prior to the characterization, the rCBs produced after each run of SWT are separated from the metallic thread and then grinded in a laboratory knife mill for $30 \mathrm{~s}$.

\section{Waste Tire Sample Characterization Methods}

\section{Determination of Weight Loss by Thermogravimetric Analysis}

Experiments have been carried out using a TG-DTA 92 SETARAM equipment. 10-40 mg of tire sample are placed in the first alumina crucible, the second one being the blank. These experiments are conducted under a nitrogen atmosphere associated with a WETSYS SETARAM controlled humidity generator starting with a $10 \mathrm{~min}$ isotherm at $30^{\circ} \mathrm{C}$, and followed by a heating rate of $5^{\circ} \mathrm{C} / \mathrm{min}$ from 30 to $800^{\circ} \mathrm{C}$. A second isotherm of $60 \mathrm{~min}$ is then applied before cooling. When temperature reaches $30^{\circ} \mathrm{C}$, a last $10 \mathrm{~min}$ isotherm closes the heating cycle.

\section{Virgin Carbon Black and rCB from Steam Water Thermolysis Characterization \\ Determination of the Specific Surface Area (ASTM D6556-10)}

The specific surface area was evaluated from the nitrogen adsorption isotherms at $77 \mathrm{~K}$ in the range of $p$ $/ p_{0}=0.05-0.30$ using the Brunauer, Emmett and Teller (BET) theory of multilayer gas adsorption behavior [27] and following the standard ASTM D6556-10 test method. The BET specific surface area was measured using a Micromeritics Gemini 2360 analyzer (Micromeritics). Prior to nitrogen adsorption, $\mathrm{rCBs}$ were degassed at $125^{\circ} \mathrm{C}$ for $24 \mathrm{~h}$ at a residual pressure of $10^{-4}$ Torr with a Micromeritics VACPrep 061 degasser. The results presented were obtained using the B.E.T equation.

\section{Determination of the Moisture Content, Ash Content and Heat of Combustion}

TG-DSC analyses were conducted on a TG-DSC 111 SETARAM. These analyses were used to determine the moisture content, some other volatile matter, the ash content and the heat of combustion for the rCBs from SWT. 10-20 mg of rCB sample placed in a platinum crucible was first heated from 30 to $125^{\circ} \mathrm{C}$ at $10^{\circ} \mathrm{C} / \mathrm{min}$, subjected to a 
$1 \mathrm{~h}$ isotherm at this temperature under air and then cooled to $30^{\circ} \mathrm{C}$ at $20^{\circ} \mathrm{C} / \mathrm{min}$ to determine the moisture and volatile matter content. $30 \mathrm{mg}$ of sample placed in a platinum crucible was also heated from 30 to $550^{\circ} \mathrm{C}$ at $10^{\circ} \mathrm{C} / \mathrm{min}$, the $550^{\circ} \mathrm{C}$ isotherm was hold for $6 \mathrm{~h}$ before cooling to $30^{\circ} \mathrm{C}$ at $20^{\circ} \mathrm{C} / \mathrm{min}$, this operation allows us to identify the ash content and the heat of combustion.

\section{Determination of Metals and Minerals Content}

The inorganic content of the rCBs was studied by inductively coupled plasma atomic emission spectroscopy (ICPAES) with an Ultima 2, Jobin-Yvon-Horiba spectrometer after a $3 \mathrm{~h}$ mineralization treatment at $80^{\circ} \mathrm{C}$ using nitric acid (69\%) and hydrochloric acid (37\%).

\section{Determination of C.H.N.S.O.}

Elemental analysis was performed using a Flash 2000 C.H.N.S./O. analyzer from Thermo Fisher Scientific.

\section{Determination of the Oil Absorption Number (ASTM D2414-09a)}

The determination of the Oil Absorption Number (OAN) for the rCBs has been achieved following the ASTM D2414-09a on a Brabender Absorptometer "C" using dibutyl phthalate (DBP) oil. The absorption of DBP in $\mathrm{mL} / 100 \mathrm{~g}$ was calculated using the equation:

$O A N=\frac{A}{B} \times 100$

where $A$ is the volume of oil used in $\mathrm{mL}$ and $B$ the mass of the tested sample in $\mathrm{g}$.

\section{Determination of the rCB Morphology}

The morphology of our particles is observed using Environmental Scanning Electronic Microscopy (ESEM Philips XL30 FEG). Coupled to an Energy Dispersive X-ray detector (EDX), the microscope has allowed us to determine qualitatively the main chemical species found in our samples and therefore confirm ICP-AES results.

\section{Mechanical Characterizations of rCBs Filled Rubbers}

\section{Apparatus}

Rheological properties of raw compounds were measured with a 1500 S Mooney (Monsanto ${ }^{\circledR}$ ) and a 2000E MDR (Moving Die Rheometer, Monsanto ${ }^{\circledR}$ ) according to test standard NF-ISO 289-1 and ISO 6502 respectively.
Mechanical behaviour of cured compounds was determined with a T2000 tensile tester (Monsanto ${ }^{\circledR}$ ) for tensile and tear properties according to NF ISO 34 and 37. Hardness (Shore A) and density were measured respectively with a durometer (Bareiss ${ }^{\circledR}$ ) according to NF ISO 7619-1, and a lab balance (Mettler Toledo ${ }^{\circledR}$ ) according to NF ISO 2781. Specific trials for the Fatigue-to-Failure Test (FTFT, Monsanto ${ }^{\circledR}$ ), compression set (during $70 \mathrm{~h}$ at $70^{\circ} \mathrm{C}$ ) and abrasion resistance $\left(\mathrm{Zwick}^{\circledR}\right)$ were conducted according to respectively NF ISO 6943, NF ISO 815-1 and NF ISO 4649.

Viscoelastic behaviour was obtained applying a strain sweep with a Rubber Process Analyzer (RPA2000_-Alpha Technologies $\left.{ }^{\circledR}\right)$. Thermal aging was performed according to NF ISO 188 conditions.

\section{Results and Discussion}

\section{Thermogravimetric Analyses at Lab Scale}

A preliminary thermogravimetric analysis (TGA-DTA) was performed on the shredded waste tires sample provided by SOREGOM and is presented in Fig. 3. The analysis was conducted under a nitrogen atmosphere with a controlled relative humidity of $50 \%$ at $40{ }^{\circ} \mathrm{C}$ to reflect at best the SWT operating conditions. Temperature was ranging from 30 to $800^{\circ} \mathrm{C}$ at a $5^{\circ} \mathrm{C} / \mathrm{min}$ heating rate according to the protocol described previously.

TG and dTG obtained from the waste tire sample suggest that degradation starts at $150{ }^{\circ} \mathrm{C}$. We are first able to determine a slight decrease in the weight loss until around $300^{\circ} \mathrm{C}$, which is attributed to the volatilization of chemicals additives such as plasticisers and processing oils originally present in a tire. Then, starting from 300 up to $575^{\circ} \mathrm{C}$, the main weight loss associated to the rubber degradation is observed. This is confirmed by the dTG curve showing an important peak in this temperature range. Indeed, the dTG curve indicates the major weight loss event to occur between 350 and $500^{\circ} \mathrm{C}$. It corresponds to the temperature range of decomposition for the major rubber components in tires such as styrene-butadiene rubber (SBR), natural rubber (NR), and polybutadiene rubber (BR). These results are in fair agreement with previous studies conducted on tires pyrolysis [28].

The decomposition seems complete after $550^{\circ} \mathrm{C}$, which implies no further weight loss. We can report that the total weight loss of our sample is close to $62 \mathrm{wt} \%$ when using nitrogen atmosphere with a controlled relative humidity. This result is equivalent to the weight loss of the sample in conventional pyrolysis conditions at the same $5^{\circ} \mathrm{C} / \mathrm{min}$ heating rate. 
Fig. 3 TGA-DTA analysis on the waste tire sample at labscale at $5^{\circ} \mathrm{C} / \mathrm{min}$ heating rate

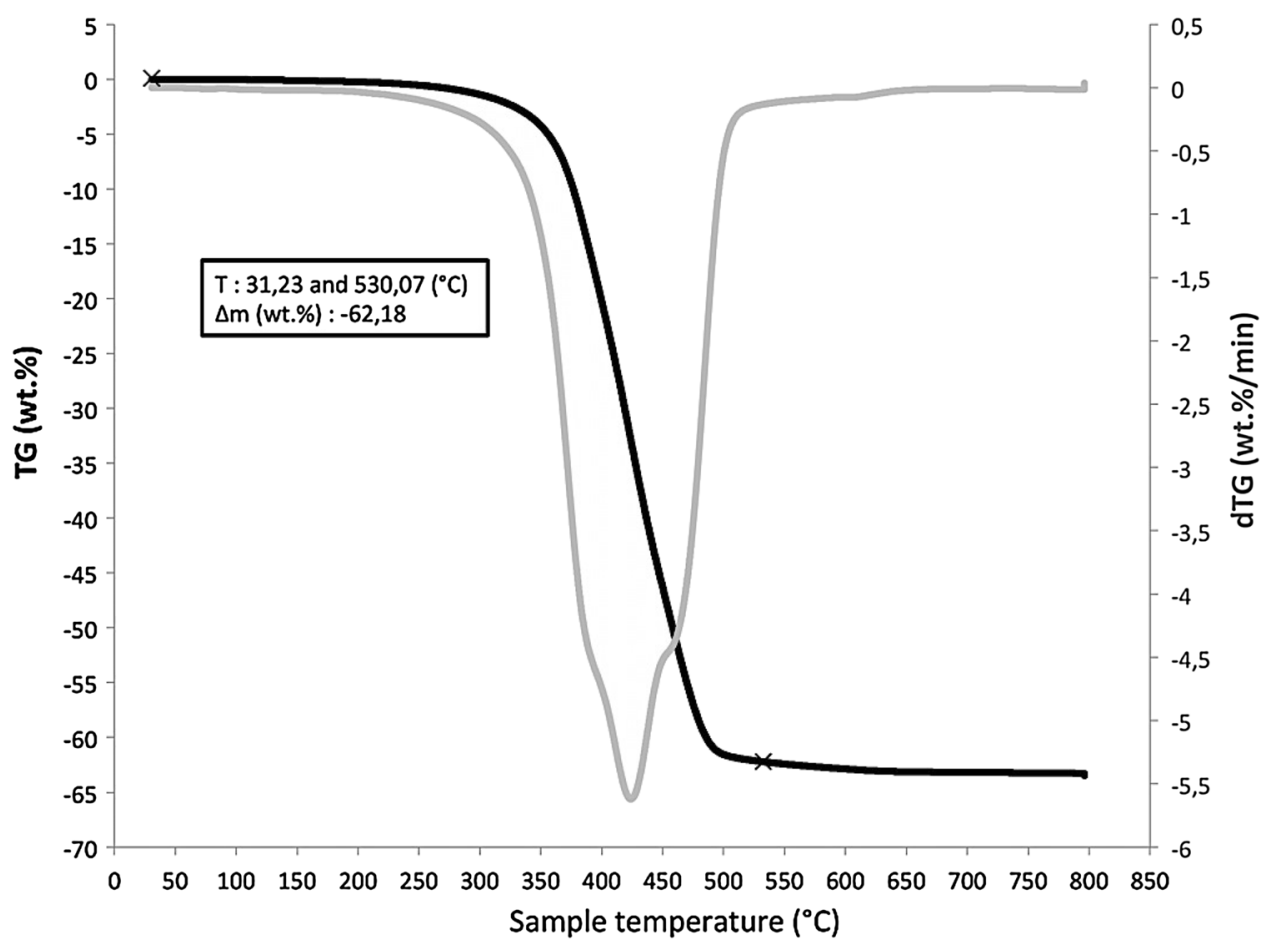

The remaining $38 \mathrm{wt} \%$ represents the solid components within the tire: carbon black/silica fillers, curing agents, textiles and residual metallic thread parts.

\section{Thermogravimetric Analyses at Pilot Scale}

The successive steps of a typical SWT trial in the pilotscale reactor are presented in Fig. 4. The diagram can be divided in 3 main stages: (i) reactor heating until the targeted temperature, (ii) introduction of tire sample corresponding to the start of both isothermal residence time and degradation process and (iii) reactor cooling. According to the thermogram displayed in Fig. 4, we can assume that the weight loss starts to stabilize 29 min after introduction of the waste tire sample into the reactor.

Table 4 shows the results of thermogravimetric measurements for the different conditions applied to our steam water thermolysis process. The weight losses for all conditions are comprised between 68.32 and $69.84 \mathrm{wt} \%$. These results are in good agreement with preliminary experiments conducted on laboratory scale equipment and show that for the designated temperature of 450 and $500{ }^{\circ} \mathrm{C}$, no significant differences on the final degradation are observed regardless of the nitrogen and/or steam water flow rates and the residence time.

The rCB yield from our thermolysis is set around $30 \mathrm{wt} \%$. Previous studies had revealed that a SWT conducted between $400^{\circ} \mathrm{C}$ might not have degraded totally the waste tire sample. Resulting rCBs have then been characterized physically and chemically.

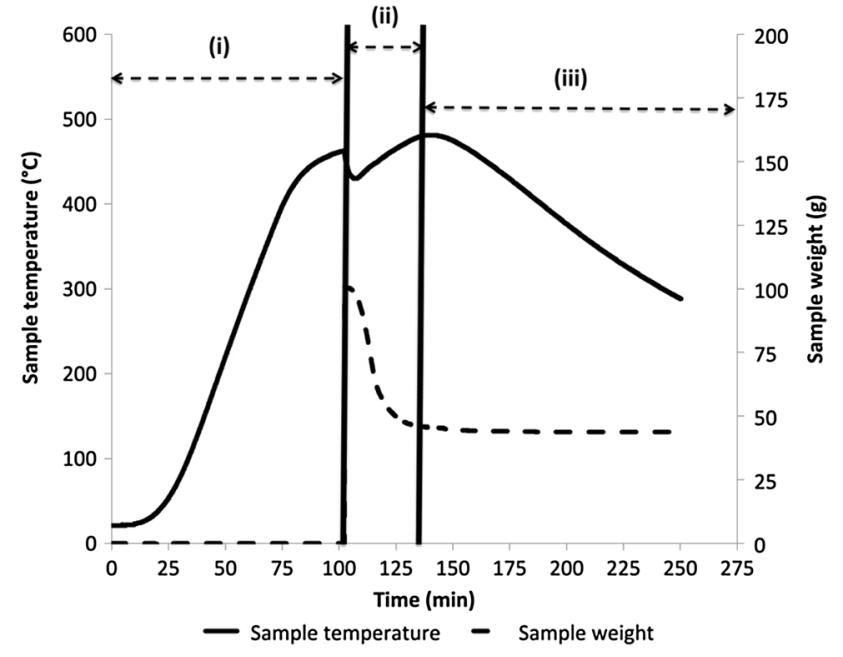

Fig. 4 Thermogram model for rCB_1 at pilot scale

Table 4 Weight losses on the waste tire samples at different operating conditions

\begin{tabular}{lllll}
\hline Sample & $\begin{array}{l}\text { Initial } \\
\text { weight } \\
\text { (g) }\end{array}$ & Final weight (g) & Metal weight (g) & $\begin{array}{l}\text { \% Weight } \\
\text { loss (metal } \\
\text { free) }\end{array}$ \\
\hline rCB_1 & 100 & 46.14 & 14.46 & 68.32 \\
rCB_2 & 100 & 41.48 & 10.51 & 69.03 \\
rCB_3 & 100 & 46.68 & 15.60 & 68.92 \\
rCB_4 & 100 & 47.87 & 17.21 & 69.34 \\
rCB_5 & 100 & 45.03 & 14.87 & 69.84 \\
rCB_6 & 100 & 42.46 & 42.46 & 69.48 \\
\hline
\end{tabular}


Table 5 Properties of $\mathrm{rCBs}$ from steam water thermolysis (rCB_1 to rCB_6 with rCB_ind from waste tires, and rCB_N330 from laboratory N330 filled rubber) in comparison with virgin N330 rubber grade carbon black

\begin{tabular}{|c|c|c|c|c|c|c|c|c|c|c|c|c|c|}
\hline & & & & N330 & rCB_1 & rCB_2 & rCB_3 & $\mathrm{rCB}$ & & $\mathrm{rCB}_{-}$ & rCB_6 & rCB-ind & rCB_N330 \\
\hline Operating con & litions & $\mathrm{T}\left({ }^{\circ} \mathrm{C}\right)$ & & - & 450 & 500 & 450 & 500 & & 450 & 450 & - & 450 \\
\hline & & Res. time (mil & & - & 30 & 30 & 60 & 60 & & 30 & 60 & - & 30 \\
\hline & & $\mathrm{N}_{2}$ flow $(\mathrm{L} / \mathrm{mi}$ & & - & 5 & 5 & 5 & 5 & & 0 & 0 & - & 0 \\
\hline & & Steam flow (g & & - & 30 & 30 & 30 & 30 & & 30 & 30 & - & 30 \\
\hline Property & ASTM stan & ndard & & & & & & & & & & & \\
\hline ASTM target va & & & & & & & & & & & & & \\
\hline $\begin{array}{l}\text { NSA } \\
\mathrm{BET}^{\mathrm{a}} \pm \mathrm{SD} \\
\left(\mathrm{m}^{2} / \mathrm{g}\right)\end{array}$ & D6556-10 & $77.21 \pm 1.36$ & 74.6 & $0 \pm 1.13$ & $80.10 \pm 2.53$ & $94.77 \pm 0.69$ & $93.06 \pm$ & 0.44 & 77.78 & \pm 0.16 & $87.41 \pm 1.69$ & $52.55 \pm 0.39$ & $76.76 \pm 9.47$ \\
\hline $\begin{array}{l}\text { OAN } \\
(\mathrm{mL} / 100 \mathrm{~g})\end{array}$ & D2414-09 & 103.2 & 100. & & 100.4 & 102.8 & 98.3 & & 88.8 & & 89.9 & 102.2 & 93.2 \\
\hline Proximate analy & is (wt\%) & & & & & & & & & & & & \\
\hline $\begin{array}{l}\text { Moisture and } \\
\text { volatiles }\end{array}$ & $\begin{array}{l}\text { D1509- } \\
95\end{array}$ & 0.22 & 0.83 & & 0.50 & 1.00 & 0.90 & & 0.60 & & 0.60 & 0.96 & 0.77 \\
\hline Ash & $1506-99$ & 0.70 & 16.1 & & 14.02 & 16.57 & 15.38 & & 15.95 & & 19.50 & 13.73 & 6.63 \\
\hline $\begin{array}{l}\text { Heat of } \\
\text { combustion } \\
(\mathrm{kJ} / \mathrm{g})\end{array}$ & - & 29.50 & 23.11 & & 23.90 & 23.50 & 19.50 & & 24.10 & & 24.10 & - & 26.40 \\
\hline Ultimate analysi & b (wt $\%)$ & & & & & & & & & & & & \\
\hline Carbon & - & 99.00 & 82.9 & & 82.69 & 81.58 & 83.60 & & 82.85 & & 81.27 & 82.65 & 94.21 \\
\hline Hydrogen & - & 0.27 & 0.55 & & 0.59 & 0.72 & 0.52 & & 0.73 & & 1.03 & 0.75 & 0.54 \\
\hline Nitrogen & - & 0.12 & 0.34 & & 0.49 & 0.43 & 0.50 & & 0.96 & & 1.08 & 0.28 & 0.35 \\
\hline Sulphur & - & 0.08 & 1.76 & & 1.97 & 1.86 & 1.47 & & 1.73 & & 1.91 & 2.07 & 1.64 \\
\hline Oxygen & - & 0.90 & 1.98 & & 2.57 & 2.01 & 2.27 & & 2.25 & & 2.55 & - & - \\
\hline Metals and mine & rals ${ }^{\mathrm{b}}$ (wt\%) & & & & & & & & & & & & \\
\hline $\mathrm{Zn}$ & - & - & 6.20 & & 5.80 & 6.29 & 7.06 & & 5.60 & & 5.47 & 4.33 & 2.88 \\
\hline $\mathrm{Si}$ & - & 0.06 & 0.15 & & 0.81 & 0.14 & 0.11 & & 0.60 & & 0.80 & 2.08 & 0.08 \\
\hline $\mathrm{Ca}$ & - & 0.05 & 1.56 & & 0.84 & 1.08 & 0.22 & & 1.00 & & 0.70 & 0.58 & 0.06 \\
\hline $\mathrm{Fe}$ & - & - & 0.33 & & 0.22 & 0.22 & 0.32 & & 0.13 & & 0.10 & 0.28 & 0.01 \\
\hline $\mathrm{Al}$ & - & - & 0.15 & & 0.22 & 0.10 & 0.14 & & 0.18 & & 0.16 & 0.26 & 0.01 \\
\hline $\mathrm{Na}$ & - & 0.05 & 0.06 & & 0.23 & 0.15 & 0.14 & & 0.20 & & 0.16 & 0.12 & 0.05 \\
\hline
\end{tabular}

${ }^{\mathrm{a} N S A ~ B E T ~ a r e ~ m e a n ~ v a l u e s ~ f r o m ~} 3$ measurements

${ }^{\mathrm{b}}$ Ultimate analysis and Metals and minerals values are mean values from at least 3 measurements, with associated standard deviations comprised within 1-25 wt\%, related to both detection sensitivity of the unit and heterogeneity of the analyzed samples

\section{rCB Characterization}

\section{Physical and Chemical Characterization}

Specific analytical test methods are performed on virgin carbon blacks to determine their chemical composition but mainly to identify if they are polluted by exogenous species such as moisture, hydrocarbons (ASTM D1509-95) and inorganics from water used along the manufacturing process (ASTM D1506-99). A comparison was made between the virgin carbon black (N330), rCBs from waste tires (rCB_1-rCB_6) at laboratory pilot scale, at the industrial pilot (rCB_ind) and from the laboratory N330 filled rubber (rCB_N330) treated by SWT. ASTM D1509-95 and D1506-99 test methods were supplemented by ultimate analyses, with a special interest in metals and minerals from ashes.

Following the results showed in Table 5, it is observed that rCBs produced from tires have a carbon content up to $83,94.21 \mathrm{wt} \%$ for the rCB obtained from the laboratory formulated rubber, and $99 \mathrm{wt} \%$ for the virgin N330 carbon black. TG-DSC analyses were performed on the rCBs following the procedure described in the experimental methods and adapted from ASTM D1509-95 standard. Heating loss of the rCBs consists primarily of moisture and other volatile materials and has been identified after a $1 \mathrm{~h}$ isotherm at $125^{\circ} \mathrm{C}$. Both the inorganic components present after combustion, better known as ash content, and the heat of combustion of the rCBs produced have been also determined. Results showed that moisture and highly volatiles 
content stay under $1 \mathrm{wt} \%$ for all samples. rCBs heats of combustion are slightly reduced, ranging from 19.5 to $26.4 \mathrm{~kJ} / \mathrm{g}$ in comparison with the $29.5 \mathrm{~kJ} / \mathrm{g}$ of virgin N330. These data do not reveal significant differences between the virgin and the $\mathrm{rCB}$ regardless of its process conditions. The main discrepancy from the proximate analysis is the ash content, which is above $14 \mathrm{wt} \%$ for all the rCBs from waste tires. This is much more important than the $0.7 \mathrm{wt} \%$ measured for the virgin N330 carbon black. This high amount of ash observed for the rCBs from tires is obviously related to the additives included during the formulation of the tire. Results from ICP-AES analyses reveal that metals and minerals content is indeed rather important. Overall, impurities found in ashes come mostly from other reinforcing fillers added to increase the mechanical properties of tires and from vulcanization agents incorporated to control the rubber curing process. The rCBs samples presented in this study mainly contain zinc, which roughly accounts for 30-40 wt $\%$ of the total inorganic components content. This result has been rather expected as zinc oxide $(\mathrm{ZnO})$ is commonly used as an activator agent in the vulcanization process in order to control the kinetics of the cross-linking reaction. Other trace metals elements such as $\mathrm{Si}, \mathrm{Ca}, \mathrm{Fe}$, $\mathrm{Al}$ and $\mathrm{Na}$ have also been detected in samples. This can be explained by the fact that minerals fillers such as $\mathrm{SiO}_{2}$ and $\mathrm{Al}_{2} \mathrm{O}_{3}$ are frequently added in the formulation of tires. A sulfur content ranging from 1 to $2 \mathrm{wt} \%$ is also detected for the rCBs. This high sulfur content in comparison with the virgin N330 comes from the curing system used for the tire formulation, where sulfur is the main cross-linking vulcanization agent.

Physical properties of carbon blacks where obtained using D2414-09 (Oil Absorption Number) and D6556-10 (Total and External Surface Area by Nitrogen Adsorption) ASTM standards. The purpose of D2414-09 standard is to ascertain the structure of carbon black by determining the amount of oil (frequently DBP) that a given mass of carbon black can absorb to fill all the voids between the aggregates before reaching a predetermined torque endpoint. High OAN measurement indicates a high-structure carbon black with aggregates characterized by an important number of primary particles. Inversely a low OAN suggests a lowstructure carbon black with aggregates consisting of only a few particles. The objective of D6556-10 is to determine the total surface area (inversely related to particle size) by the Brunauer, Emmett, and Teller (B.E.T. NSA) theory of multilayer gas adsorption behavior using multipoint determinations. Both standards allow the carbon black manufacturers and rubber industries to classify virgin carbon blacks for rubber products (ASTM D1765-10) and to assess the reinforcing behavior of the fillers.

According to these ASTM target values, specific surface area measurements versus Oil Absorption Numbers are reported in Figs. 5, 6 and 7. Figure 5 shows the effect of the steam water thermolysis parameters on physical properties of $\mathrm{rCB}$. The influence of residence time on specific surface area for 2 samples at 450 and $500{ }^{\circ} \mathrm{C}$, increasing from 74 to $77 \mathrm{~m}^{2} / \mathrm{g}$ for $30 \mathrm{~min}$ to $93-94 \mathrm{~m}^{2} / \mathrm{g}$ for $60 \mathrm{~min}$, is clearly observed. The superheated steam water is suspected to have an impact on the rCBs porosity considering the residence time parameter.

Figure 6 reports the influence of the nitrogen flow on carbon black structure and bear out the influence of residence time on specific surface area. Results display an increase of the OAN from around $88-89 \mathrm{~mL} / 100 \mathrm{~g}$ without nitrogen flow up to $100-102.8 \mathrm{~mL} / 100 \mathrm{~g}$ with nitrogen flow for the respective same processing conditions $\left(\mathrm{T}^{\circ} \mathrm{C}=450^{\circ} \mathrm{C}\right.$, steam water flow $\left.=30 \mathrm{~g} / \mathrm{h}\right)$ while an improvement of the specific surface area is still observed from 30 to $60 \mathrm{~min}$ residence time. The addition of a nitrogen flow to the superheated steam must enhance the heat exchanges by convection phenomena.

Figure 7 gives a typical diagram of the major carbon blacks used for the formulation of tires in comparison with the products obtained during this study. According to their specific surface area and OAN reported in this study, rCBs obtained from SWT hold both structure and particle size quite close to a carbon black from the N300 grade.

\section{Morphology of the $\mathrm{rCBs}$}

An Environmental Scanning Electron Microscopy was used to examine the morphology of the rCBs. Figure 8 displays the micrographs of particles from a sample obtained by the SWT process for specific operating conditions in comparison with a virgin N330 carbon black. Figure 8a, c show respectively agglomerates of a few micrometers revealing the pseudo-spherical and elongated shape of the $\mathrm{rCB}$ whereas the N330 exhibits a well-defined spherical shape. At higher magnifications, the rCB agglomerate presented in Fig. $8 \mathrm{~b}$ is still composed of aggregates in the form of chainlike clusters after the thermochemical treatment, which corresponds to what is also observed for the N330 displayed in Fig. 8d. As expected, the main noticeable difference concerns the appearance of minerals and metals components at the surface of some rCBs agglomerates. The main chemical species in the sample have been examined during the microscopic study using an EDX detector. The results presented in Fig. 9 indicate that the main minerals and metals present in the sample are in good agreement with the previous ICP-AES analysis: $\mathrm{Zn}, \mathrm{Al}, \mathrm{Si}$, or $\mathrm{Ca}$. According to this brief morphological study, the observations reveal the rCB and the virgin carbon black morphologies to be quite similar.

It was demonstrated that $\mathrm{rCB}_{-} 1$ to $\mathrm{rCB} \_6$ have physical properties close to a virgin N330 carbon black. 


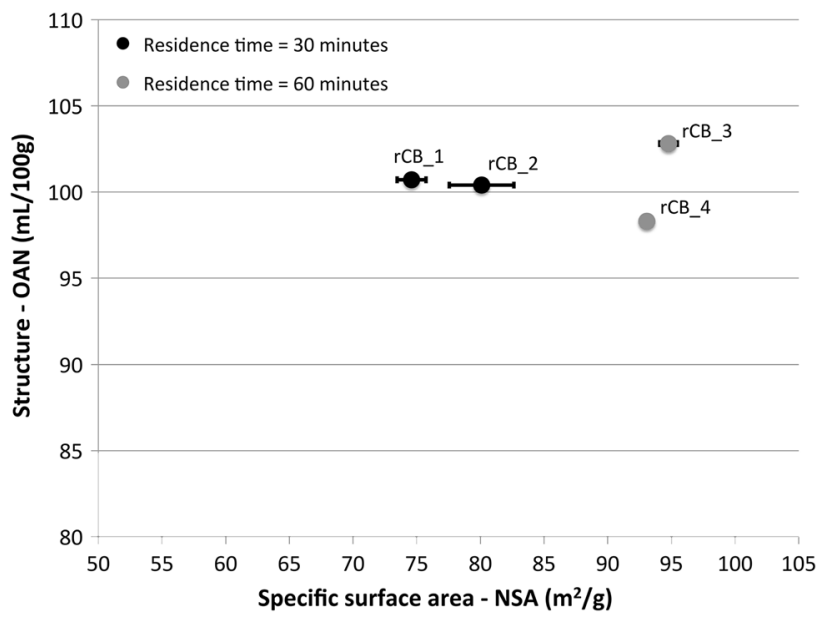

Fig. 5 Effect of steam water thermolysis residence time on ASTM target values (OAN and NSA) for $\mathrm{rCB}_{-} 1$ and $\mathrm{rCB} \_3$ (at $450^{\circ} \mathrm{C}$ ) compared to rCB_2 and rCB_4 (at $500^{\circ} \mathrm{C}$ )

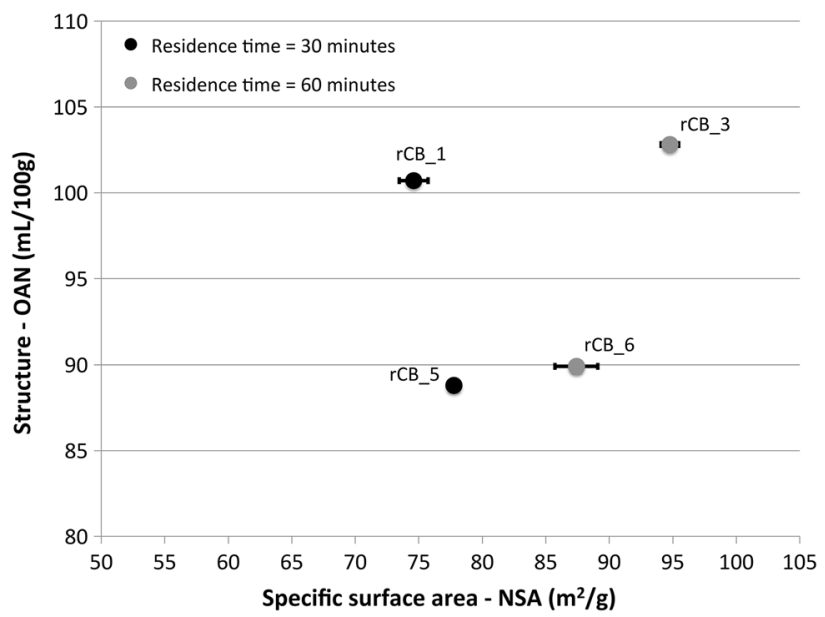

Fig. 6 Effect of steam water thermolysis nitrogen flow on ASTM target values (OAN and NSA) for rCB_1 and rCB_3 (with $\mathrm{N}_{2}$ flow) compared to rCB_5 and rCB_6 (without $\mathrm{N}_{2}$ flow) at a $450^{\circ} \mathrm{C}$ temperature

However the rCBs obtained are actually assumed to be a combination of all the carbon black grades used in a tire, added to an important amount of inorganic components and to possible residues in the form of carbonaceous deposits [27]. Consequently, even if the chemical and physical properties of $\mathrm{rCB}$ are in good agreement with the virgin N330 carbon black, all of these standardized tests were developed for virgin carbon blacks and too little feedback has been reported in scientific literature about the relationship between ASTM standards and rCBs. It is therefore difficult to conclude unequivocally that these standards should not be used to predict the in-rubber performance of the rCB filler or to study the mechanism of reinforcement [29].
The specific surface area value of $52.55 \mathrm{~m}^{2} / \mathrm{g}$ for the rCB_ind obtained at the pre-industrial scale is generally lower than the values for all rCBs obtained in the laboratory reactor. This discrepancy could be explained by a non-optimization of the process operating conditions on the pre-industrial pilot, especially regarding the residence time parameter (30 min).

Results presented so far in this paper should only give a first insight on the real physicochemical properties of the product. Rheometric and mechanical tests have been carried out in order to evaluate and assess more clearly the reinforcing properties of the rCBs from SWT. These test have been performed on the two following samples: rCB_ind and rCB_N330.

\section{Rheometric and Mechanical Properties}

\section{Compounds with $100 \%$ of $r C B$}

Properties of two compounds composed of $100 \%$ of each rCB ( $\mathrm{rCB}$ _ind and rCB_N330) were compared to the three references N772, N550 and N330.

Rheometric controls at $160{ }^{\circ} \mathrm{C}$ were done to compare the cure properties of the different compounds depending on the recovered fillers at $100 \%$. An increase of both scorch and curing times is observed in Table 6 for the rCB_N330 whereas the same characteristic times are observed for the rCB_ind compared to the N330 carbon black reference. This phenomenon could be explained by a possible difference on surface activity (and so reactivity) of these two rCB samples during the SWT process. Concerning the final cured properties, the two rCBs show a level of cross-linking density of vulcanization between N772 and N550 references as seen in Fig. 10. Mooney

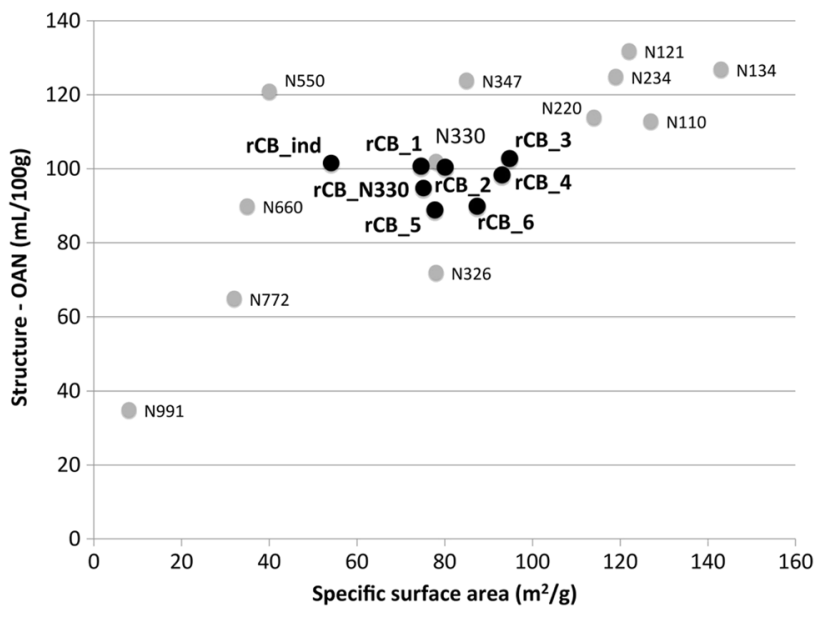

Fig. 7 rCBs from steam water thermolysis relative to ASTM rubber grades 

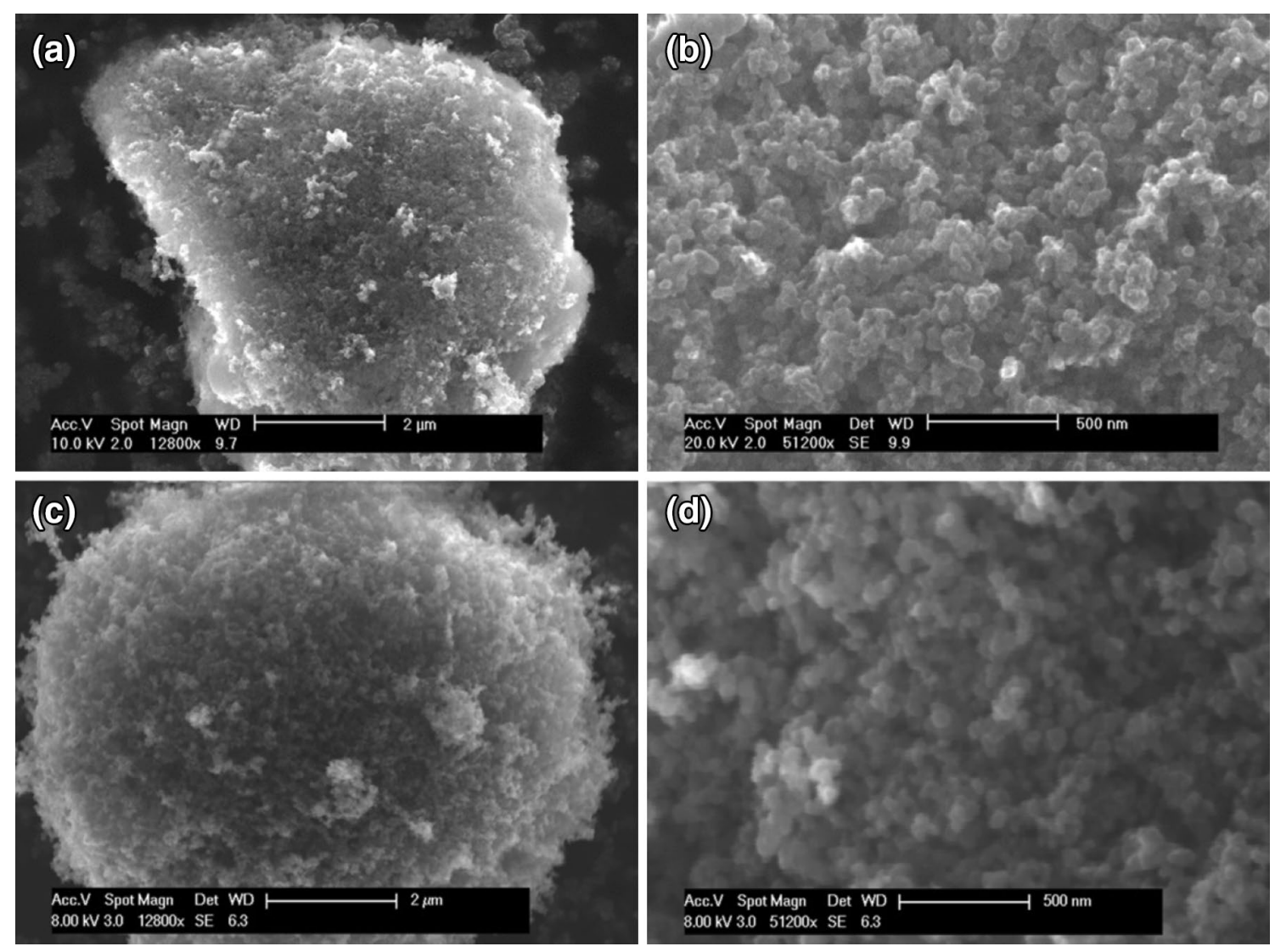

Fig. 8 ESEM micrographs of $\mathbf{a}-\mathbf{b}$ rCB_1 sample and $\mathbf{c}-\mathbf{d}$ N330 rubber grade carbon black

consistence at $100{ }^{\circ} \mathrm{C}$ is 24 and $38 \mathrm{MU}$ for $\mathrm{rCB}$ _ind and rCB_N330 respectively. Viscosity of the two compounds is then clearly different with a value closer to N330 reference (41 MU) when rCB N330 is used.
Mechanical properties of these two compounds were compared to three virgin carbon blacks (N772, N550 and $\mathrm{N} 330$ ) at initial and after heating conditions.

Considering unaged compounds, the investigated mechanical properties in Table 7 showed close values
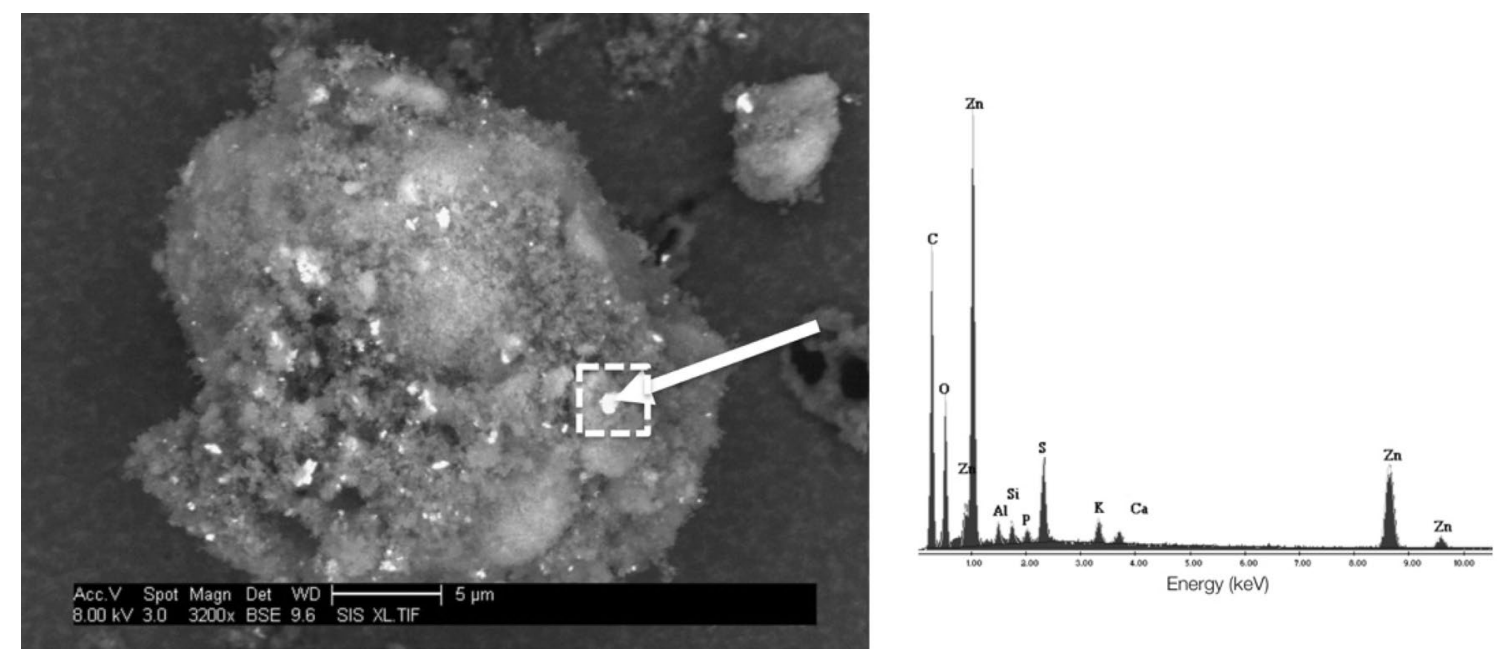

Fig. 9 ESEM micrograph of rCB_1 sample and its EDX spectrum from one point on the sample 
Fig. 10 Rheometric properties at $160{ }^{\circ} \mathrm{C}$ of $100 \% \mathrm{rCBs}$ compounds
Table 6 Rheometric properties at $160{ }^{\circ} \mathrm{C}$ of $100 \% \mathrm{rCBs}$ compounds

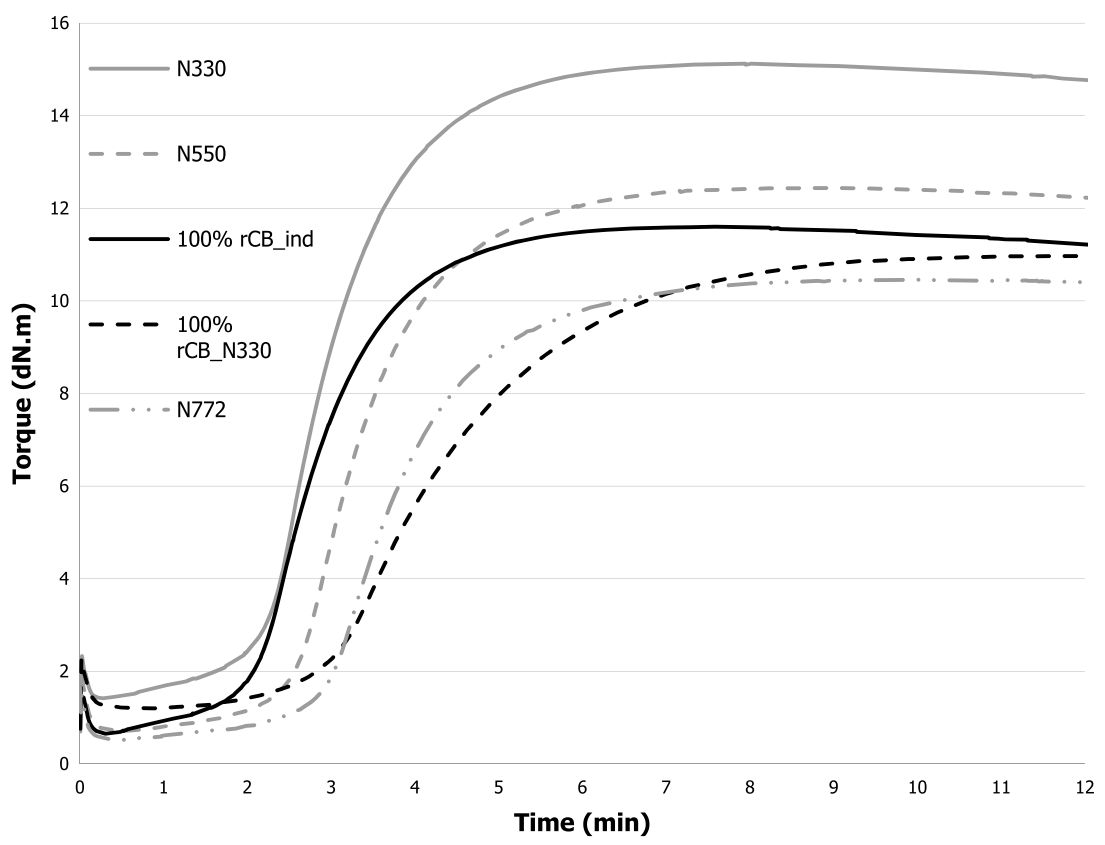

\begin{tabular}{llllll}
\hline & $\mathrm{N} 772$ & $\mathrm{~N} 550$ & $\mathrm{~N} 330$ & 100\% rCB_ind & 100\% rCB_N330 \\
\hline $\mathrm{ML}(1+4)$ @ $100^{\circ} \mathrm{C}(\mathrm{MU})$ & 21 & 31 & 41 & 24 & 38 \\
Torque min $(\mathrm{dN} \mathrm{m})$ & 0.5 & 0.8 & 1.7 & 0.7 & 1.2 \\
Torque max (dN m) & 10.3 & 12.6 & 15.4 & 11.6 & 11.0 \\
$\mathrm{~T}_{\max }-\mathrm{Tm} \min (\mathrm{dN} \mathrm{m})$ & 9.8 & 11.8 & 13.7 & 10.9 & 9.8 \\
$\mathrm{ts}_{2}$ (min:s) & $2: 45$ & $2: 38$ & $2: 14$ & $02: 14$ & $03: 21$ \\
$\mathrm{t}_{98}$ (min:s) & $7: 13$ & $6: 27$ & $5: 49$ & $05: 31$ & $08: 50$ \\
\hline
\end{tabular}

Table 7 Mechanical properties of cured 100\% rCBs compounds

\begin{tabular}{|c|c|c|c|c|c|}
\hline & N772 & N550 & N330 & $\begin{array}{l}100 \% \\
\text { rCB_ind }\end{array}$ & $\begin{array}{l}100 \% \\
\text { rCB } \\
\text { N330 }\end{array}$ \\
\hline $\begin{array}{l}\text { Shore A hardness } \\
\text { (point) }\end{array}$ & 50 & 55 & 61 & 53 & 54 \\
\hline Density & 1.11 & 1.12 & 1.11 & 1.11 & 1.12 \\
\hline $\begin{array}{l}\text { Tensile strength } \\
\text { (MPa) }\end{array}$ & 24.0 & 22.6 & 26.4 & 22.3 & 23.5 \\
\hline $\begin{array}{l}\text { Elongation at break } \\
(\%)\end{array}$ & 617 & 562 & 578 & 600 & 629 \\
\hline M100\% (MPa) & 1.4 & 2.0 & 2.2 & 1.5 & 1.5 \\
\hline M300\% (MPa) & 7.0 & 9.5 & 11.2 & 7.2 & 6.8 \\
\hline M100/M300 & 4.9 & 4.7 & 5.2 & 4.8 & 4.5 \\
\hline Delft tear $(\mathrm{N})$ & 120 & 97 & 145 & 148 & 105 \\
\hline Compression set (\%) & 39 & 35 & 40 & 44 & 43 \\
\hline Abrasion $\left(\mathrm{mm}^{3}\right)$ & 163 & 146 & 114 & 138 & 173 \\
\hline FTFT $\left(\times 10^{3}\right)$ & 69 & 58 & 89 & 48 & 62 \\
\hline
\end{tabular}

Table 8 Mechanical properties of compounds after thermal aging at $70^{\circ} \mathrm{C}$ during $70 \mathrm{~h}$

\begin{tabular}{lll}
\hline & N330 reference & rCB_N330 \\
\hline$\Delta$ Hardness (points) & 3 & 6 \\
$\Delta$ Tensile strength (MPa) & 2.4 & 3.0 \\
$\Delta$ Elongation at break (\%) & -34 & -37 \\
$\Delta \mathrm{M} 100(\mathrm{MPa})$ & 0.7 & 0.5 \\
$\Delta \mathrm{M} 300(\mathrm{MPa})$ & 3.3 & 2.8 \\
\hline
\end{tabular}

between both rCB-based compounds, except for delft tear, abrasion and fatigue resistance. No significant influence of ash content was observed. When $\mathrm{rCB}$ was introduced at $100 \%$ in this formula, mechanical properties were close to N550 reference for hardness, rupture properties (tensile strength and elongation at break), delft tear, abrasion resistance and fatigue test. The level of reinforcement (100 and $300 \%$ modulus) is the unique less performing property, compared to N550 reference, for both rCB samples. Both of these rCBs from SWT give the same reinforcement properties as the N772 grade. Table 8 indicates the same 


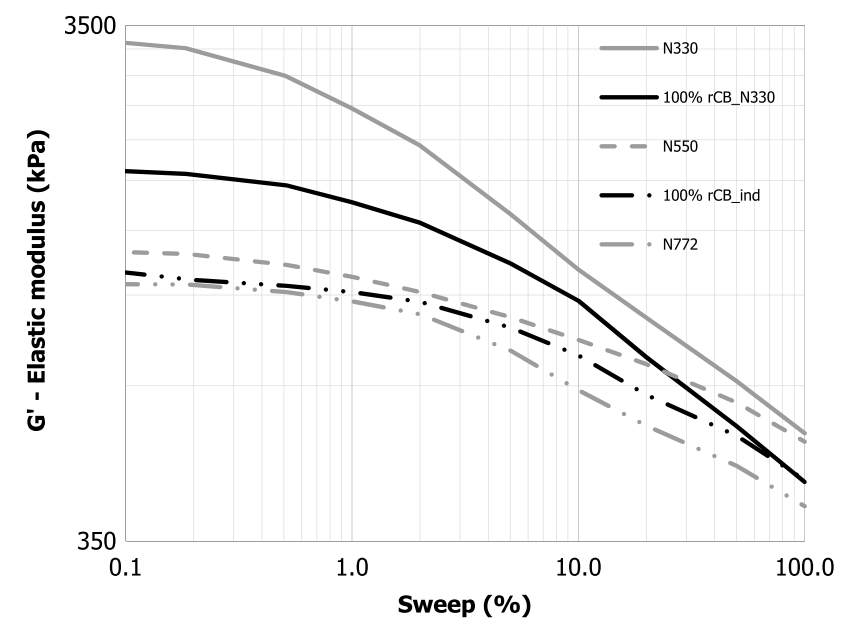

Fig. 11 RPA strain sweeps of cured 100\% rCB compounds

hardness and strain properties variations after a thermal aging of $70 \mathrm{~h}$ at $70^{\circ} \mathrm{C}$ for the rCB_N330 in comparison to the $\mathrm{N} 330$ reference.

Figure 11 displays the viscoelastic properties of both compounds determined by RPA tests. A lowering of the elastic modulus $\mathrm{G}^{\prime}$ at $0.1 \%$ of strain and Payne Effect $\left(\Delta \mathrm{G}^{\prime}\right)$ was observed when rCB_ind is used. Moreover, rCB_ind curve matches with the one for the N772 reference whereas the behaviour of the rCB_N330 curve seems to be closer to the N330 reference. Mechanical properties from RPA analysis confirm a level of performance of rCB_ind similar to N772 reference. Inversely, rCB obtained from the N330 rubber model formulation brings better level of properties, intermediate between N330 and N550 carbon black grades. Thus, a difference between both grades of rCBs is observed, which can not only be attributed to ash content itself.

Fig. 12 Mechanical properties of cured rCB_ind compounds

\section{Compounds with Blend rCB_ind and N330 Standard Carbon Black}

To improve the level of properties, two others compounds were realised with two different blends:

- $20 \%$ of rCB_ind and $80 \%$ of N330,

- $50 \%$ of rCB_ind and 50\% of N330.

Observations of mechanical properties in Fig. 12 and curves from RPA tests in Fig. 13 show that when the proportion of $\mathrm{rCB}$ ind increased, their physical properties became lower than N330 reference. When 20\% of the filler amount is constituted of rCB_ind, properties are similar to N330 reference even for the 100 and $300 \%$ modulus. Inversely, $50 \%$ of rCB_ind with $50 \%$ of N330 indicate a clear decrease of modulus and fatigue

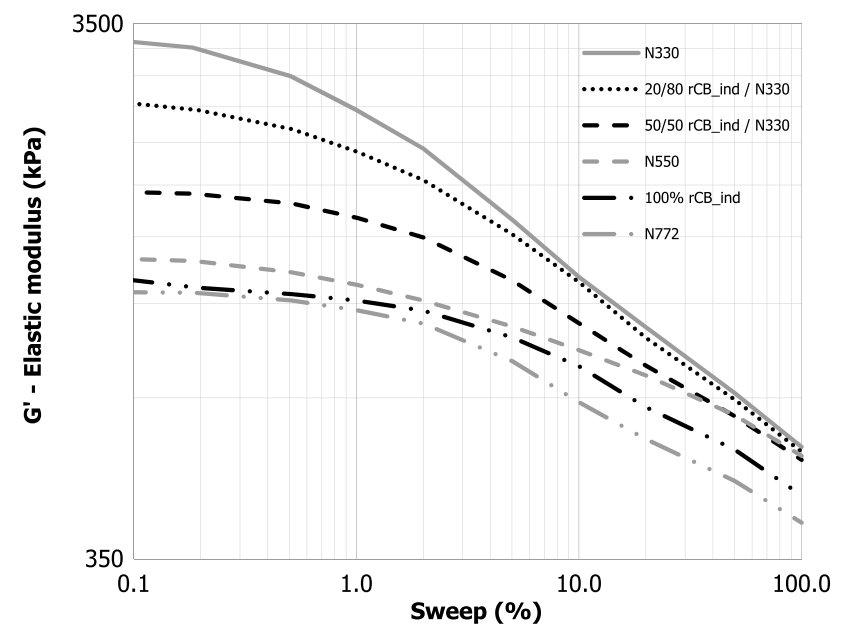

Fig. 13 RPA strain sweeps of cured rCB_ind compounds

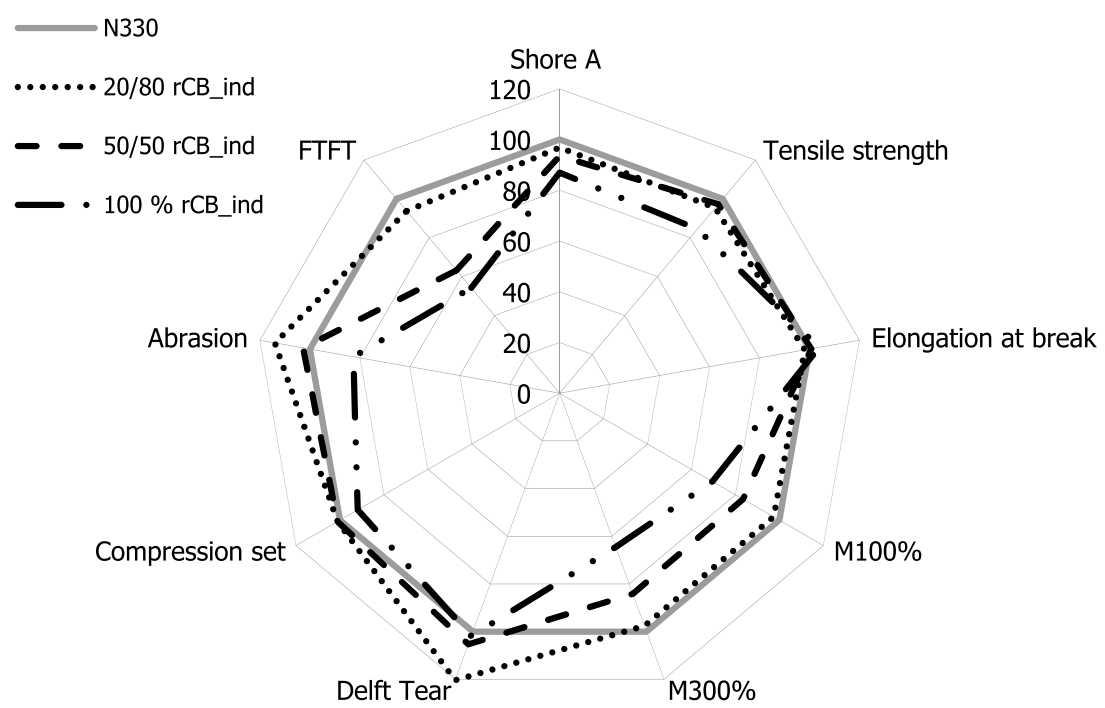


resistance. In this case, global properties were closer to the $100 \%$ rCB_ind compound.

Results presented in this study for the rCBs exhibit a mechanical behaviour inferior to what has been observed for the N330 filled vulcanized rubbers. The noticeable difference in terms of carbon content, ash content and all the other inorganic components found in the recovered product are generally the main reasons advanced to explain the loss of mechanical properties. Roy and coworkers [30] have nevertheless studied extensively rCBs or pyrolytic carbon black recovered from waste tires using a vacuum pyrolysis treatment process. By conducting more fundamental surface characterizations, they have shown that carbonaceous deposits coming from the decomposition of elastomers are formed on the original carbon black. These deposits were found responsible for the reduction of available interactions sites at the surface of the recovered filler.

A significant decrease of filler-rubber interactions can be therefore suspected in our study, leading to a low degree of reinforcement and affecting the overall in-rubber performance of rCBs.

\section{Conclusion}

The tire industry uses principally N330 carbon black, which has a specific surface area of $78 \mathrm{~m}^{2} / \mathrm{g}$ and an oil absorption number of $102 \mathrm{~mL} / \mathrm{g}$. As shown in this paper, specific surface area and oil absorption number of rCBs obtained from SWT are very close to N330 values.

Rubber manufacturers systematically compare reinforcing properties of rCBs to the N330 grade. However, the general reinforcement potential of the recovered filler is lower than a N330 carbon black especially concerning the $100 \%$ modulus, the $300 \%$ modulus and the fatigue resistance. Rheometric and mechanical properties have appeared to be closer to $\mathrm{N} 772$ grade. Currently, rCB contains an amount of ashes close to $20 \mathrm{wt} \%$ (less than $1 \%$ for conventional carbon black), mainly composed of inorganic matter coming from compounding components used during tire manufacturing. It is likely that this high ash content decreases the reinforcing properties. This might be the reason why such a material still encounters some difficulties being sold to tire manufacturers and why it is confined to niche markets in the rubber or plastics industries. So far, rCBs are addressed to plastic and rubber industries for nontechnical products. However, the dissemination of the $\mathrm{rCB}$ product in the rubber industry is still limited because of its intrinsic physical and chemical properties. The ash content and its constituents oblige the users to modify their formulations and then develop an entirely new product containing rCB. Furthermore, the mechanical resistance of rubber filled with $\mathrm{rCB}$ is lower than the same rubber filled with virgin carbon black. Ash content is thus undeniably a barrier for the broad acceptance of $\mathrm{rCB}$ in the marketplace.

Nevertheless, preliminary studies presented in this paper have shown that, even when a model laboratory filled rubber is treated, the in-rubber performance stays considerably reduced. According to the 6-7 wt $\%$ ash content of the rCB_N330 coming from the model rubber, we can suspect without difficulty that the loss of reinforcing properties can not only be attributed to a considerable amount of ashes. It seems like a more widespread recognition from the scientific community and related industries has to be acknowledged regarding rCBs surface interactions with rubber. Work in our laboratory is already in progress to give a deeper understanding of rCB filler-rubber interaction. To do so, advanced physical and chemical characterization such as Raman Spectroscopy, Transmission Electron Microscopy, X-ray Photoelectron Spectroscopy and Time of Flight SIMS will be performed on the rCBs surface.

Acknowledgements Partial funding was received for this work from the French Association for Research and Technology (ANRT) and is gratefully acknowledged. In-rubber performance studies have been performed under the framework of the BIOPROOF project partially funded by the French government (BPIFRANCE). The authors also wish to acknowledge Celine Boachon and Christine Rolland from the Centre RAPSODEE for technical support.

\section{References}

1. Shulman, V.L., European tyre recycling association, Conference, Introduction to tyre recycling (2016)

2. Sienkiewicz, M., Kucinska-Lipka, J., Janik, H., Balas, A.: Progress in used tyres management in the European Union: a review. Waste Manag. 32, 1742-1751 (2012)

3. Williams, P.T.: Pyrolysis of waste tyres: a review. Waste Manag. 33, 1714-1728 (2013)

4. Wojtowicz, M.A., Serio, M.A.: Pyrolysis of scrap tires: can it be profitable. Chemtech. 48-53 (1996)

5. Zhang, Y., Hwang, J.-Y., Peng, Z., Andriese, M., Li, B., Huang, X., Wang, X.: Microwave absorption characteristics of tire. In: Carpenter, J.S., Bai, C., Escobedo, J.P., Hwang, J.-Y., Ikhmayies, S., Li, B., Li, J., Monteiro, S.N., Peng, Z., Zhang, M. (eds) Characterization of Minerals, Metals, and Materials. Wiley, Hoboken (2015)

6. Martinez, J.D., Puy, N., Murillo, R., García, T., Navarro, M.V., Mastral, A.M.: Waste tyre pyrolysis-a review. Renew. Sust. Energy Rev. 23, 179-213 (2013)

7. Cunliffe, A. M., Williams, P. T.: Composition of oils derived from the batch pyrolysis of tyres. J. Anal. App. Pyrol. 44, 131152 (1998)

8. Pakdel, H., Roy, C., Aubin, H., Jean, G., Coulombe, S.: Formation of limonene in used tyre vacuum pyrolysis oils. Environ. Sci. Technol. 25, 1646-1649 (1991)

9. Kalitko, V.A.: Steam-thermal processing of used tires: calculation of the rate of explosion-proof feed of steam. InzhenernoFizicheskii Zhurnal. 81(4), 750-754 (2008) 
10. Oliveira Nunes, A.: Composites renforcés à fibres de carbone : récupération des fibres par vapo-thermolyse, optimisation du procédé. PhD Thesis, École des Mines d'Albi-Carmaux (2015)

11. Merchant, A.A., Petrich, M.A.: Pyrolysis of scrap tires and conversion of chars to activated carbon. AIChE J. 39 (8), 1370-1376 (1993)

12. Murillo, R., Navarro, M.V., García, T., López, J.M., Callén, M.S., Aylón, E., Mastral, A.M.: Production and application of activated carbons made from waste tire. Ind. Eng. Chem. Res. 44(18), 7228-7233 (2005)

13. Zabaniotou, A., Madau, P., Jung, C.G., Delplancke, M.P., Fontana, A.: Active carbon production from used tire in two-stage procedure: industrial pyrolysis and bench scale activation with $\mathrm{H}_{2} \mathrm{O}-\mathrm{CO}_{2}$ mixture. J. Anal. Appl. Pyrol. 72, 289-297 (2004)

14. Zabaniotou, A., Oudenne, P.D., Jung, C.G., Fontana, A.: Activated carbon production from char issued from used tyres pyrolysis: industrial improvement. Erdöl, Erdgas Kohle. 121(4), 160162 (2005)

15. Roy, C., Chaala, A., Darmstadt, H., de Caumia, B., Pakdel, H., Yang, J.: Conversion of used tires to carbon black and oil pyrolysis. In: De, S.K., Isayev, A., Khait, K. (eds.) Rubber recycling. CRC Press, New York (2005)

16. Martinez, J.D., Murillo, R., García, T.: Production of carbon black from the waste tires pyrolysis. Bol. Grupo Español. Carbon. 30, 10-14 (2013)

17. Zhang, X., Wang, T., Ma, L., Chang, J.: Vacuum pyrolysis of waste tires with basic additives. Waste Manag. 28, 2301-2310 (2008)

18. Acosta, R., Tavera, C., Gauthier-Maradei, P., Nabarlatz, D.: Production of oil and char by intermediate pyrolysis of scrap tyres: influence on yield and product characteristics. J. Chem. React. Eng. 13(2), 189-200 (2015)

19. Norris, C.J., Hale, M., Bennett, M.: Pyrolytic carbon: factors controlling in-rubber performance. Plast. Rubber Compos. 43, 245-256 (2014)
20. Cataldo, F.: Preparation of pyrolytic carbon black from scrap tire rubber crumb and evaluation in new rubber compounds. Macromol. Mater. Eng. 290, 463-467 (2005)

21. Karabork, F., Tipirdamaz, S.T.: Influence of pyrolytic carbon black and pyrolytic oil made from used tires on the curing and (dynamic) mechanical properties of natural rubber (NR)/styrenebutadiene rubber (SBR) blends. Express Polym. Lett. 10(1), 72-82 (2016)

22. Du, A.H., Wu, M.S., Su, C.Y., Chen, H.: The characterization of pyrolytic carbon black prepared from used tires and its application in styrene-butadiene rubber (SBR). J. Macromol. Sci. B. 47, 268-275 (2008)

23. Athanassiades, E.: Waste tyre pyrolysis: Sustainable recovery and reuse of a valuable resource. $\mathrm{PhD}$ thesis - Imperial College London, (2013)

24. Du, A., Zhang, Z., Wu, M.: The effect of pyrolytic carbon black prepared from junked tires on the properties of ethylene-propylene-diene copolymers (EPDM). Express Polym. Lett. 3, 295-301 (2009)

25. Pech, J.L.: Method for treating carbonaceous materials by vapor thermolysis. WO2014135754 (A1), 2014-09-12

26. Sheng, Y.Y., Bounaceur, A., Soudais, Y., Barna, R.: Parameter optimization of the steam thermolysis: a process to recover carbon fibers from polymer-matrix composites. Waste Biomass Valor. 4(1), 73-86 (2013)

27. Brunauer, S., Emmett, P.H., Teller, E.: J. Am. Chem. Soc. 60, 309 (1938)

28. Williams, P.T., Besler, S.: Pyrolysis-thermogravimetric analysis of tyres and tyres components. Fuel. 74(9), 1277-1283 (1995)

29. Gerspacher, M.: Advanced CB characterizations to better understand polymer-filler interaction. Kaut. Gummi Kunstst. 62(5), 233-239 (2009)

30. Roy, C., Chaala, A., Darmstadt, H.: The vacuum pyrolysis of used tires end-uses for oil and carbon black products. J. Anal. Appl. Pyrol. 51, 201-221 (1999) 